\title{
Evaluating Winter Barley Cultivar Using Data Envelopment Analysis Models
}

\author{
Masoud Hashemi ${ }^{1}$, Omid Reza Zandvakili ${ }^{1}$, Roohollah Abbasi Shureshjani ${ }^{2}$, Fatemeh Etemadi ${ }^{1}$ \\ $\&$ Heather Darby ${ }^{3}$ \\ ${ }^{1}$ Stockbridge School of Agriculture, University of Massachusetts, Amherst, MA, USA \\ 2 Department of Management, Hazrate Masoumeh University, Qom, Iran \\ ${ }^{3}$ The University of Vermont, St. Albans, VT, USA \\ Correspondence: Omid Reza Zandvakili, Stockbridge School of Agriculture, University of Massachusetts, \\ Amherst, MA 01003, USA. E-mail: ozandvakili@umass.edu
}

Received: February 24, 2019

Accepted: March 31, $2019 \quad$ Online Published: May 15, 2019

doi:10.5539/jas.v11n6p22

URL: https://doi.org/10.5539/jas.v11n6p22

\begin{abstract}
Unlike feed barley, malting barley must meet a specific set of quality standards for acceptability by maltsters. Multiple quality criteria in addition to the grain yield makes ranking of genotypes challenging. The objective of this study was to apply data envelopment analysis (DEA) models to rank the efficiencies of 27 winter barley entries based on grain yield and quality indices. Four methods of DEA including Charnes, Cooper and Rhodes (CCR), Färe and Grosskopf (FG), Banker, Charnes and Cooper (BCC), and Seiford and Thrall (ST) used for the ranking. Testing trial included 14 two-rows and 13 six-rows winter barley. All entries except two, demonstrated high winter survival ratings. Overall, the six-row cultivars out-yielded the two-row cultivars by $18 \%$. However, in terms of brewing quality, the two-row entries performed better than six-row entries and had 40\% lower thinness, $12 \%$ higher plump, and lower grain protein content. The six-row entries had 32\% higher germinative energy than two-row entries. The ranking by four models were not similar, however, SU-Mateo and Calypso had the highest efficiency (1.0) by all four models followed by Wintmalt and Vincenta.
\end{abstract}

Keywords: brewing quality indices, DEA, malting barley, ranking efficiency, winter barley

\section{Introduction}

In the United Sates, unlike previous decades, the majority of barley is currently grown for malting purposes, rather than for animal feed (Mallet, 2014). The shift in the purpose of cultivating barley is at least partly due to significant increasing demand for local food and beverage consumption. Small malt houses and craft brewers are constantly looking to locally produced barley grain production to meet their demand.

Unlike feed barley, malt barley must meet a specific set of quality standards for acceptability by maltsters. Since malt barley commands a significantly higher price than feed barley, moderate high-quality yield is preferred to the high yielding but low quality barley (O’Donovan et al., 2011; USDA, 2015).

The brewing barley must be free of disease, frost damage, pre-harvest sprouted, weathering, heat damage during storage, chemical residues, smut and ergot, and broken kernels (BMBRI, 2010). Moreover, the protein content of the grains should be around 105-125 $\mathrm{g} \mathrm{kg}^{-1}$ since higher protein levels reduce the amount of extractable malt (McFarland et al., 2014). In general, six-row barley varieties usually have higher protein content ranging from 90-120 $\mathrm{g} \mathrm{kg}^{-1}$, compared to two-row barley varieties, which range from 90-110 $\mathrm{g} \mathrm{kg}^{-1}$ (Magliano et al., 2014). Higher protein levels is often associated with lower starch content. Starch is the principal contributor to malt house extract, and high starch content results in more beer produced from a given amount of malt, although some small-scale breweries are minimally concerned with malt house extract efficiency. Barley grain must have a minimum of $70 \%$ plump kernels (Wrigley, 2010). Percent plump is the percentage of all kernels retained above the $0.24 \times 1.91 \mathrm{~cm}$ screen. Higher plump is desirable, as plumb kernels produce higher amount of extractable malt by weight (Johnson \& Nganje, 2000). Percent thin is the percentage of kernels passing through the $0.20 \times$ $1.91 \mathrm{~cm}$ screen. Unlike plump, high percent thin is considered undesirable due to low malt extraction by weight. Kernels need to be greater than $85 \%$ plump and of uniform size to produce more malt. Test weight, a measure of grain plumpness, is also an indicator used by malsters for evaluating malt quality. Higher test weight is favorable 
by maltsters. However, acceptable values of protein and plumpness might be modified depending on the quality of harvested malting barley (Smith et al., 2016). Malting barley must not have a falling number below 200 (Darby et al., 2014), since low falling number indicates degradation of the grain starches due to increased alpha-amylase activity from pre-harvest sprouting (MacArthur et al., 2009). Barley grains should have a minimum germinative energy (kernels germinated after 72 hours) of $95 \%$, since un-germinated grains do not convert the stored starches to simpler sugars, mainly maltose, which is required for malt production. Deoxynivalenol (DON) toxin in grain, which is due to fungal infestation, is a major criterion for acceptability of barley for brewing. DON level above $1.0 \mathrm{ppm}$ results in rejection by malt houses, though tolerance from the malt houses may vary depending on the quality of the grain supply that year (Smith et al., 2016). Acceptable DON level for most craft cultivar breweries is below $0.5 \mathrm{ppm}$. This is primarily due to the 'gushing', or over foaming that can occur in the finished beer when even very low levels of the mycotoxin may present (Johnson \& Nganje, 2000; Mallet, 2014). Test weight is an important component of evaluating quality and value of barley grain. Falling number is not a standard quality measurement at malt houses. However, research indicates that a falling number of 220 seconds and greater is associated with high malt barley quality.

Agronomists constantly perform testing trials to evaluate and select high yielding cultivars to be used by growers in various regions. However, evaluation of malting barley genotypes is quite challenging. In testing trials of malting barley, the ranking and selection of the entries must include several quality parameters, in addition to the grain yield and possibly the tolerance to a specific stress condition such as winter hardiness.

DEA is a non-parametric technique used to determine inefficiencies in evaluating systems with multiple inputs and outputs (Banker et al., 2011). This technique has been employed since its introduction in 1978 (Charnes et al., 1978) in a wide range of industries, most commonly in banking, healthcare, human resources and education. Applications of this model to agronomic systems are more limited (Emrouznejad et al., 2008). The applicability of this model to evaluation of genotypes in agronomic research has recently been demonstrated (Etemadi et al., 2017), where the efficiency of eight faba bean cultivars calculated based on four agronomic traits. In applying this methodology to a cultivar trial, when all traditional agronomic inputs (labor, fertilizer, etc.) are equal across treatments, undesirable traits (excess protein, high DON levels, thin kernels) can be considered as inputs and desirable traits (high grain yield, test weight, plump kernels, germination energy and falling number) as outputs. The standard extension testing trials often conducted in a single location, and the results disseminated to the growers in that region. Local growers may find multiple rankings of cultivars based on various characteristics, an inefficient way to select the favorable cultivar. Providing a single, regionally specific ranking will help simplify selection of the most appropriate cultivar for the growers needs.

The main objective of this study was to apply DEA models to evaluate and rank the efficiencies of 27 barley entries based on their grain yield and quality indices including test weight, protein level, DON, percentage of plumpness and thinness.

\section{Materials and Methods}

\subsection{Experimental Site}

This trial was conducted at the University of Massachusetts Agricultural Experiment Station Farm in S. Deerfield, MA $\left(42^{\circ} \mathrm{N}, 73^{\circ} \mathrm{W}\right)$. Soil at this site in the Connecticut River Valley is characterized as fine Hadley loam. Soil sample from the top $15 \mathrm{~cm}$ of soil collected by sampling a $5 \times 4$ grid of 20 sub-samples across the block. The block was then amended appropriately as recommended by the University of Massachusetts soil-testing lab for barley production. On September 25, 2015, all barley entries were planted into the experimental block, which had been left fallow over the preceding season, following a 2014 winter rye cover crop. Experimental plots were $0.5 \mathrm{~m}$ wide and $1.5 \mathrm{~m}$ long and seeded at $123 \mathrm{~kg} \mathrm{ha}^{-1}$.

\subsection{Experimental Layout}

Treatments consisted of 27 winter cultivars (Table 1) supplied to the University of Massachusetts through its participation in the national Winter Malting Barley Trial, organized by the University of Minnesota. All entries replicated three times in a randomized complete block design. The variety Wintmalt was planted as buffer strips to prevent edge effect. 
Table 1. List of winter malting barley entries and days to $50 \%$ heading

\begin{tabular}{|c|c|c|c|c|c|}
\hline Cultivar Entry & Row type & Submitter & Commercially Available & Winter survival rating & $\% 50$ heading (Julian) \\
\hline Calypso & 2 & Limagrain & $x$ & 8.8 & 140 \\
\hline $10 / 069 / 1$ & 6 & Ackermann & & 8.9 & 138 \\
\hline McGregor & 6 & Check & $x$ & 8.9 & 138 \\
\hline Puffin & 6 & Ohio State & $x$ & 8.8 & 142 \\
\hline Vincenta & 2 & Ackermann & & 8.5 & 139 \\
\hline SU-Mateo & 2 & Ackermann & & 8.8 & 140 \\
\hline 6W11-0003 & 6 & Busch Ag & & 8.7 & 140 \\
\hline Thoroughbred & 6 & Check & $x$ & 9.0 & 133 \\
\hline Wintmalt & 2 & Check & $\times$ & 8.6 & 143 \\
\hline MW12_4042-002 & 6 & U. Minnesota & & 8.8 & 136 \\
\hline MW12_4007-008 & 6 & U. Minnesota & & 8.9 & 136 \\
\hline 6W11-0064 & 6 & Busch Ag & & 8.8 & 141 \\
\hline Hirondella $(08 / 258 / 17)$ & 6 & Ackermann & & 8.8 & 140 \\
\hline 10.0777 & 2 & Oregon State & & 9.0 & 135 \\
\hline Strider & 6 & Check & $x$ & 9.0 & 140 \\
\hline MW11S4024-004 & 6 & U. Minnesota & & 8.8 & 134 \\
\hline 02Ab669 & 2 & USDA & & 8.8 & 139 \\
\hline 6W13-7041 & 6 & Busch Ag & & 8.8 & 144 \\
\hline 04ARS640-1 & 2 & USDA & & 9.0 & 137 \\
\hline 05ARS561-208 & 2 & USDA & & 8.4 & 142 \\
\hline MW11S4029-002 & 6 & U. Minnesota & & 8.8 & 141 \\
\hline Endeavor & 2 & Check & $x$ & 8.6 & 138 \\
\hline 06ARS633-10 & 2 & USDA & & 8.4 & 141 \\
\hline 10.086 & 2 & Oregon State & & 8.8 & 137 \\
\hline Charles & 2 & Check & $x$ & 8.7 & 136 \\
\hline DH130004 & 2 & Oregon State & & 2.0 & 140 \\
\hline DH130718 & 2 & Oregon State & & 0.3 & 143 \\
\hline
\end{tabular}

\subsection{Measurements}

\subsubsection{Harvest and Quality Analysis}

All entries harvested using a 1995 ALMACO SPC20 plot combine on July 21, 2016. Grain yields standardized to $13.5 \%$ moisture. Sub samples from each plot were stored in a $37.8^{\circ} \mathrm{C}$ until being processed and shipped to the University of North Dakota cereal grains testing facility for malt quality analysis.

Total protein $\left(\mathrm{g} \mathrm{kg}^{-1}\right)$, color and moisture, based on a dry-matter, was determined by near infrared transmittance on an Infratec 1241 grain analyzer (FOSS, 8091 Wallace Rd., Eden Prairie, MN 55344, USA). Barley plumpness $(100 \mathrm{~g})$ kernel assortment was determined using a Sortimat (Pfeuffer GmbH, Flugplatzstraße 70, 97318Kitzingen, Germany) (Methods of Analysis of the American Society of Brewing Chemists, 2004). Deoxynivalenol (DON) expressed in ppm and was determined by gas chromatography (Gas Chromatography with Electron Capture Detection by Tacke and Casper: Journal of AOAC International, Vol. 79, No. 2, 1996). Falling number was determined by a TecMaster RVA unit (PertenInstruments, Hägersten, Sweden). Germinative Energy was determined by ASBC method Barley 3-C (Methods of Analysis of the American Society of Brewing Chemists, 2004). Thin percentage is the percentage of kernels passing through the $14.3 \times 8.6 \mathrm{~cm}$ screen.

\subsection{DEA Analysis: Generalized DEA/AR Model}

In this study, GAMS software utilized to evaluate the efficiency of malting barley entries through four models including CCR, BCC, FG, and ST. We considered $x_{i j}(i=1, \ldots, m)$ and $y_{r j}(r=1, \ldots, s)$ as the positive inputs and outputs of $D M U_{j}(j=1, \ldots, n)$, thus the generalized DEA model can be formulated as below (Yu et al., 1996): 


$$
\begin{aligned}
Z= & \max \sum_{r=1}^{s} u_{r} y_{r o}-\delta_{1} u_{0} \\
& \text { s.t. } \sum_{i=1}^{m} v_{i} x_{i o}=1 \\
& \sum_{r=1}^{s} u_{r} y_{r j}-\sum_{i=1}^{m} v_{i} x_{i j}-\delta_{1} u_{0} \leq 0 \quad(j=1, \ldots, n) \\
& \delta_{1} \delta_{2}(-1)^{\delta_{3}} u_{0} \geq 0, v_{i}, u_{r} \geq 0 \quad(i=1, \ldots, m ; r=1, \ldots, s)
\end{aligned}
$$

where, $\delta_{1}, \delta_{2}, \delta_{3}$ are binary parameters:

(i) If $\delta_{1}=0$ then the generalized DEA model is reduced to the CCR model.

(ii) If $\delta_{1}=1$ and $\delta_{2}=0$ then the generalized DEA model is reduced to the BCC model.

(iii) If $\delta_{1}=\delta_{2}=1, \delta_{1}$ and $\delta_{3}=0$ then the generalized DEA model is reduced to the FG model.

(iv) If $\delta_{1}=\delta_{2}=\delta_{3}=1$, then the generalized DEA model reduced to the ST model.

However, in reality additional information or assumptions may rise that should be considered when using these models. For example, some of the weights in a DEA problem might need to be restricted. For this reason, Zhou et al. (2012) developed model (1) into the following model:

$$
\begin{aligned}
Z= & \max \sum_{r=1}^{s} u_{r} y_{r o}-\delta_{1} u_{0} \\
& \text { s.t. } \sum_{i=1}^{m} v_{i} x_{i o}=1 \\
& \sum_{r=1}^{s} u_{r} y_{r j}-\sum_{i=1}^{m} v_{i} x_{i j}-\delta_{1} u_{0} \leq 0 \quad(j=1, \ldots, n) \\
& C_{p q}^{L} v_{p} \leq v_{q} \leq C_{p q}^{U} v_{p} \quad(1 \leq p<q=2, \ldots, m) \\
& D_{p q}^{L} u_{p} \leq u_{q} \leq D_{p q}^{U} u_{p} \quad(1 \leq p<q=2, \ldots, s) \\
& \delta_{1} \delta_{2}(-1)^{\delta_{3}} u_{0} \geq 0 \quad\left(v_{i}, u_{r} \geq 0 ; i=1, \ldots, m ; r=1, \ldots, s\right)
\end{aligned}
$$

Here, the assumption is that $0 \leq C_{p q}{ }^{L}<C_{p q}{ }^{U}$ and $0 \leq D_{p q}{ }^{L}<D_{p q}{ }^{U}$.

However quite often, one of the inputs, say $x_{1}$, can be considered as an "input numeraire" and one of the outputs, say $y_{1}$, as an "output numeraire" (Thompson et al., 1992). In this case, the assurance regions are simplified as:

$$
C_{1 q}^{L} v_{1} \leq v_{q} \leq C_{1 q}^{U} v_{1}(q=2, \ldots, m) \text { and } D_{1 q}^{L} u_{1} \leq u_{q} \leq D_{1 q}^{U} u_{1}(q=2, \ldots, s)
$$

\subsection{Statistical Analysis}

Data were analyzed using PROC GLM in SAS version 9.4, and Tukeys HSD at P $\leq 0.05$ determined the significance of relationships between seeding rates to any of the measured indices.

\section{Results and Discussion}

\subsection{Weather}

Although the total precipitation in fall 2015 was almost similar to the norm for the experimental location, the main winter barley growing season (March-July 2016) was significantly dryer $(280 \mathrm{~mm})$ than the norm (452 $\mathrm{mm})$ for the experimental location.

The 2016 growing season was also warmer than the norm for the location where crop collected 306 more thermal units (Data not shown). Therefore, the spring green-up occurred earlier thus the earliest maturity entries (Throughbred and MW11S4024-004), headed in mid-May, that was about 6 days earlier than the average for this location.

\subsection{Genotypes Grain Yield}

In this study, 14 two-row and 13 six-row genotypes evaluated (Table 1). The tested genotypes varied significantly in terms of grain yield and quality (Table 2). All tested entries except DH130004 and DH130718 demonstrated high winter survival ratings (Table 1). Consequently, these two non-hardy enough entries produced the lowest grain yield. On average, six-row cultivars out-yielded the two-row cultivars by approximately $18 \%$. This could be partly due to the poor winter survival of DH130004 and DH130718, which were two-row cultivars. Due to more uniform germination, the two-row type malting barley preferred by local maltsters and craft brewers. 
Interestingly the highest grain yield $\left(8,053 \mathrm{~kg} \mathrm{ha}^{-1}\right)$ obtained from Calypso, which is a two-row cultivar followed by McGregor (7,464 kg ha-1), a six-row cultivar (Table 2). Other high grain yield entries were 10/069/1 and Hirondella, both six-row, which yielded 6,840 , and $6,810 \mathrm{~kg} \mathrm{ha}^{-1}$, respectively.

Table 2. Grain yield and malting quality parameters of tested winter barley cultivars

\begin{tabular}{|c|c|c|c|c|c|c|c|c|}
\hline Cultivar Entry & $\begin{array}{l}\text { Yield } \\
\left(\mathrm{kg} \mathrm{ha}^{-1}\right)\end{array}$ & $\begin{array}{l}\text { Test weight } \\
\left(\mathrm{kg} \mathrm{hl}^{-1}\right)\end{array}$ & Plump (\%) & Thin (\%) & $\begin{array}{l}\text { Germination } \\
\text { Energy (\%) }\end{array}$ & $\begin{array}{l}\text { Protein } \\
\left(\mathrm{g} \mathrm{kg}^{-1}\right)\end{array}$ & ${ }^{\mathrm{x}} \mathrm{DON}(\mathrm{ppm})$ & $\begin{array}{l}\text { Falling } \\
\text { number (sec) }\end{array}$ \\
\hline Calypso & 8053 & 61.6 & 97.4 & 0.6 & 99.3 & 133 & 0.01 & 350 \\
\hline McGregor & 7464 & 55.8 & 81.3 & 1.7 & 99.0 & 148 & 0.02 & 236 \\
\hline $10 / 069 / 1$ & 6840 & 56.9 & 92.0 & 1.0 & 98.0 & 129 & 0.00 & 298 \\
\hline Hirondella & 6810 & 57.2 & 94.0 & 1.0 & 99.7 & 129 & 0.00 & 272 \\
\hline Vincenta & 6544 & 56.8 & 94.8 & 0.6 & 96.7 & 116 & 0.00 & 123 \\
\hline SU-Mateo & 6392 & 60.8 & 97.0 & 0.3 & 100.0 & 106 & 0.00 & 311 \\
\hline 6W11-0003 & 6310 & 54.2 & 54.6 & 6.7 & 99.0 & 120 & 0.07 & 121 \\
\hline Puffin & 6189 & 62.2 & 93.7 & 1.1 & 98.7 & 133 & 0.00 & 321 \\
\hline Wintmalt & 5996 & 59.4 & 96.0 & 0.6 & 97.3 & 110 & 0.00 & 142 \\
\hline MW12_4042-002 & 5986 & 57.2 & 85.7 & 1.0 & 96.7 & 124 & 0.00 & 176 \\
\hline MW12_4007-008 & 5784 & 58.1 & 81.7 & 1.5 & 96.7 & 131 & 0.02 & 62 \\
\hline 6W11-0064 & 5695 & 55.7 & 69.0 & 2.1 & 99.7 & 129 & 0.01 & 150 \\
\hline Strider & 5658 & 53.6 & 66.7 & 5.9 & 89.7 & 124 & 0.05 & 200 \\
\hline 10.0777 & 5471 & 55.2 & 91.6 & 1.0 & 30.7 & 136 & 0.02 & 60 \\
\hline Thoroughbred & 5413 & 60.4 & 86.7 & 1.3 & 98.7 & 132 & 0.07 & 311 \\
\hline MW11S4024-004 & 5391 & 57.7 & 79.3 & 1.2 & 99.3 & 135 & 0.00 & 238 \\
\hline 02Ab669 & 5192 & 55.9 & 82.8 & 1.9 & 66.0 & 119 & 0.01 & 127 \\
\hline 6W13-7041 & 5190 & 52.9 & 73.1 & 2.8 & 99.0 & 130 & 0.00 & 161 \\
\hline 04ARS640 & 5027 & 58.7 & 82.2 & 1.9 & 38.7 & 138 & 0.04 & 60 \\
\hline 05ARS561 & 4596 & 49.9 & 77.1 & 4.0 & 74.0 & 114 & 0.00 & 60 \\
\hline MW11S4029-002 & 4569 & 58.3 & 59.5 & 3.2 & 99.0 & 149 & 0.01 & 200 \\
\hline Endeavor & 4471 & 57.5 & 78.2 & 1.7 & 50.3 & 130 & 0.00 & 60 \\
\hline 06ARS633 & 4409 & 50.2 & 81.6 & 2.2 & 39.7 & 114 & 0.00 & 60 \\
\hline 10.086 & 4270 & 54.8 & 91.6 & 1.4 & 34.3 & 124 & 0.00 & 60 \\
\hline Charles & 3833 & 50.0 & 91.3 & 1.4 & 60.3 & 121 & 0.00 & 60 \\
\hline DH130004 & 3179 & 55.5 & 94.5 & 1.3 & 73.7 & 146 & 0.00 & 60 \\
\hline DH130718 & 1027 & 55.9 & 95.2 & 1.5 & 74.7 & 137 & 0.00 & 60 \\
\hline Mean & 5359 & 56.4 & 84.0 & 1.9 & 81.9 & 128 & 0.01 & 161 \\
\hline LSD & 1483 & 2.3 & 10.8 & 2.0 & 13.3 & 21 & $\mathrm{~ns}$ & 94 \\
\hline 2-row mean & 4890 & 55.9 & 89.4 & 1.4 & 67.0 & 125 & 0.01 & 114 \\
\hline 6-row mean & 5946 & 56.9 & 78.3 & 2.3 & 97.9 & 135 & 0.02 & 211 \\
\hline Difference & $* * *$ & $* * *$ & $* * *$ & $* *$ & $<0.0001$ & $*$ & $\mathrm{~ns}$ & $* * *$ \\
\hline
\end{tabular}

Note. ${ }^{* *}, \mathrm{P} \leq 0.01 ; * * *, \mathrm{P} \leq 0.001 ; \mathrm{ns}$, non-significant, ${ }^{\mathrm{x}}$ Deoxynivalenol.

\subsection{Test Weight}

Test weight indicates how well the kernels filled during the grain-filling period and commonly used as one of the grain quality indicators. The higher the test weight the higher the quality for brewing purpose. Great variations in test weight of brewing barley genotypes have been reported (Brouwer et al., 2016; Kratochvil, 2017). However, environmental factors especially conditions during grain filling period could also dramatically influence the test weight of barley grains (Stevens et al., 2015). In current study, test weight of entries ranged as low as 49.9 (05ARS561) to $62.2 \mathrm{~kg} \mathrm{~h}^{-1}$ in Puffin (Table 2). Other entries, which ranked high in test weight, included Calypso, SU-Mateo, and Thoroughbred with 61.6, 60.8, and $60.4 \mathrm{~kg} \mathrm{hl}^{-1}$, respectively. Pasynkov et al. (2017) considered a test weight of 68-73 $\mathrm{kg} \mathrm{hl}^{-1}$ as the best for brewing purpose in Czech. Obviousley none of the tested entries were in this range. 


\subsection{Falling Number}

The entries demonstrated dramatic variations in their falling number, which ranged from 60 to 350 seconds (Table 2). A falling number of $220 \mathrm{~s}$ or lower indicates that some of the grains sprouted which negatively influence the malting quality (Brouwer et al., 2016). Overall, seven of the 27 entries had falling numbers above 220 seconds (Table 2). The highest falling number measured in Calypso (350), Thoroughbred (311), and SU-Mateo (310) seconds. Falling number is controlled by both genotype and environment conditions (MacArthur et al., 2009). Factors contributing to pre-harvest sprouting include temperature, and also timing and duration of precipitation following anthesis (Brouwer et al., 2016). Overall, the six-row entries performed better than two-rows in regard to the falling number (Table 2).

\subsection{Protein}

The protein level of entries varied between 106 and $149 \mathrm{~g} \mathrm{~kg}^{-1}$ (Table 2). MW11S4029-002 had the highest protein content (149 $\mathrm{g} \mathrm{kg}^{-1}$ ), followed by McGregor and DH130004 which contained 148 and $146 \mathrm{~g} \mathrm{~kg}^{-1}$, respectively (Table 2). For malting purpose, high quality barley typically contains low to moderate protein levels ranging from 90-110 $\mathrm{g} \mathrm{kg}^{-1}$. The AMBA guidelines (2018) for all malt two-row specify grain protein level below $120 \mathrm{~g} \mathrm{~kg}^{-1}(12 \%)$. Lower crude protein is desirable from a malting perspective since high protein levels can make beer hazy and lower starch content, which is the principal contributor to the brewed extract. In current study, majority of entries did not meet the acceptable protein level for malting. Although Calypso produced the highest grain weight among all entries, its protein content $\left(133 \mathrm{~g} \mathrm{~kg}^{-1}\right)$ can be a limiting factor for brewing acceptability in Northeast. On average, six-row barley contained $5.6 \mathrm{~g} \mathrm{~kg}^{-1}$ more protein than the two-row entries (Table 3).

\subsection{Germination Energy}

Malting is a germination process and barley varieties with GE values higher than $95 \%$ ( 72 hours) considered as ideal commercial malt criteria (AMBA, 2018). Out of 27 participated entries, fifteen entries met the current industry malting standards for seed germination (Table 2). Although four two-row entries had GE of above the acceptable standard, on average, six-row entries performed better than the two-row entries. Khokonova et al. (2015) stated that barley grains obtain the energy necessary for germination, which is crucial for mating purpose, during their post-harvest duration.

\subsection{Plump Kernels}

Plumpness is an important quality index for brewing barley. According to AMBA (2018), grains with 90\% or higher plump produce desired extract yield, which is an important economic factor to the brewers. However, barley with plump higher than $75 \%$ may produce relatively high-quality malt (Brouwer et al., 2016). In current study, plump kernels ranged from $54.6 \%$ to $97.4 \%$ (Table 2). In this study, the two-row entries performed better, and their plum was roughly $12 \%$ higher than six-row genotypes.

\subsection{Percent Thin}

According to the AMBA guideline (2018), the percent thin for 2-row and 6-row barley cultivars should be below $3 \%$. All two-row entries had acceptable percent thin whereas some of six-row entries including 6W11-0003 (6.7\%), Strider (5.9\%), and 05ARS561 (4\%), were above the standard acceptable value for percent thin. The lowest thin percent belonged to SU-Mateo with $0.3 \%$, followed by Calypso, Vincenta, and Wintmalt all with $0.6 \%$. Averaged over the entries, the two-row barley performed much better in regard to their thin percent which was roughly $40 \%$ lower than six-row entries. Barley cultivars with lower thin percent absorb water fasters, and a high percentage of thins may cause problems with malt homogeneity.

\subsection{DON}

DON level of barley grains indicates the degree of fungal infestation and DON values above $1.0 \mathrm{ppm}$ results in rejection by malt houses. All winter barley entries in this trial exhibited DON values below the FDA's 1 ppm limit (Table 2). However, the acceptable DON value by many craft malt houses is even lower $(0.5 \mathrm{ppm})$ than the standard acceptability set by AMBA (2018). This is primarily due to the over foaming of beers when barley grains are infected with even very low levels of the mycotoxin (Johnson and Nganje, 2000; Mallet, 2014).

\subsection{Efficiency of Entries}

In this study seven major quality traits including test weight, falling number, protein $\%$, germination energy, plump kernel, thin \%, and DON in addition to the grain yield for ranking of the entries using four DEA/AR models were considered. To analyze the data by the models, the inputs and outputs of the DEA model was predefined. The larger values for grain yield, falling number, germination energy, plump kernel, and test weight was considered favorable, whereas lower values for protein percent, thinness, and DON considered desirable. As expected, none of the 
entries met all the quality criteria considered favorable for malting purpose. Data envelope analysis allow for the integration of grain yield and quality indices into a single ranking in each of the four tested models. The results revealed that SU-Mateo and Calypso had the highest efficiency (1.0) calculated by all four models (Figures 1-4). The lowest efficiency varied between less than 0.2 in DH130718, when CCR and FG models used, and 0.65 in MW002 when BCC and ST models performed. Based on CCR and FG models, 10 entries had efficiencies above the average (0.7) whereas 12 entries ranked better than average efficiency (0.8), when BCC and ST models performed.

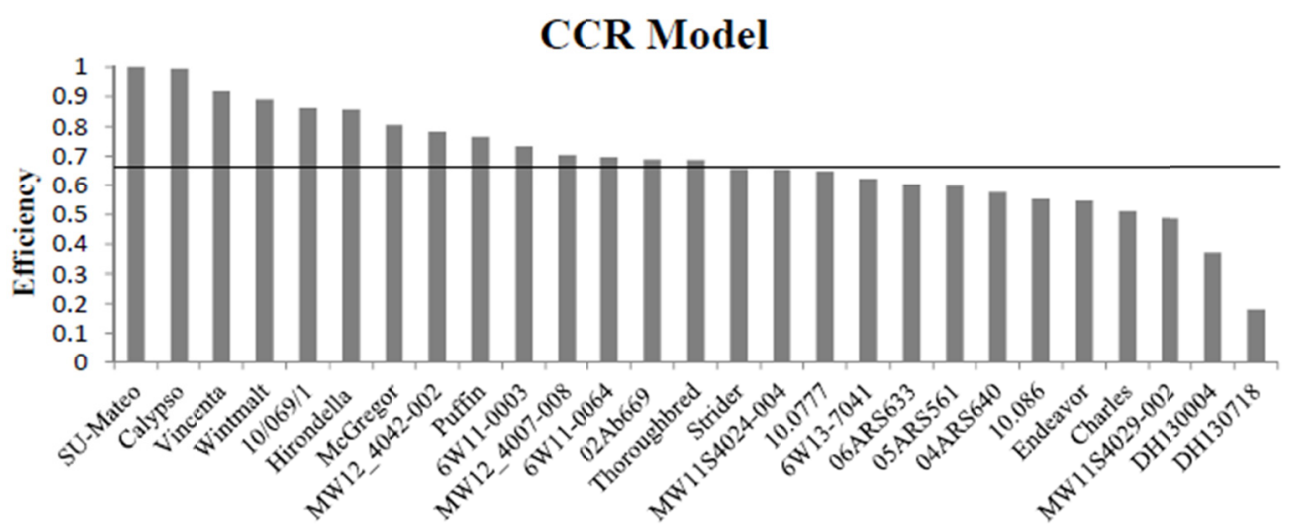

Figure 1. Efficiency ranking of winter barley entries, using the CCR model

\section{BCC Model}

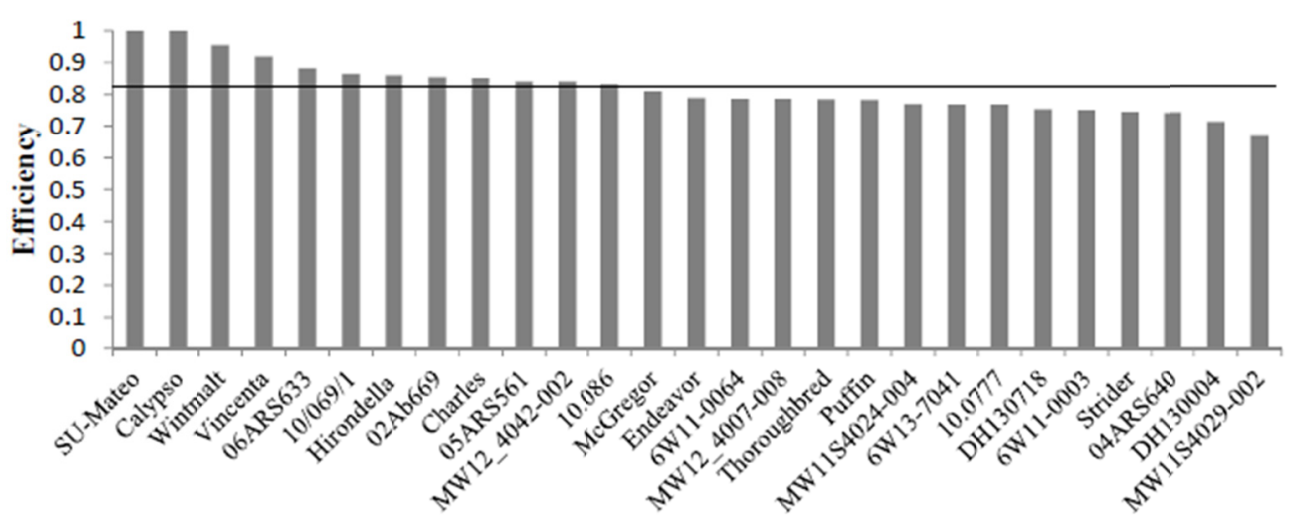

Figure 2. Efficiency ranking of winter barley varieties using the BCC model

\section{FG Model}

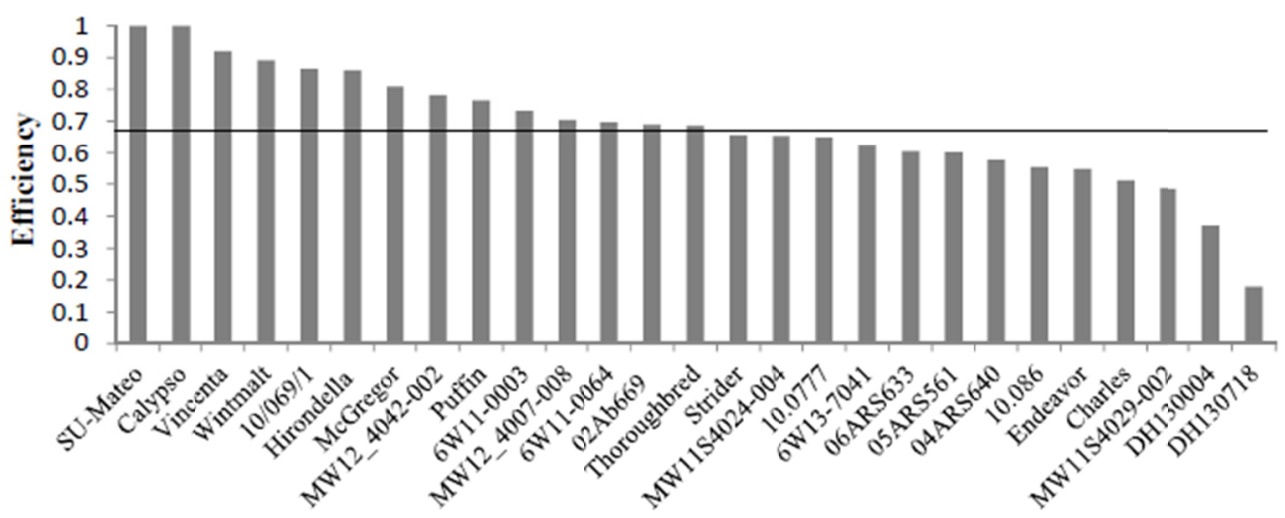

Figure 3. Efficiency ranking of winter barley varieties using the FG model 


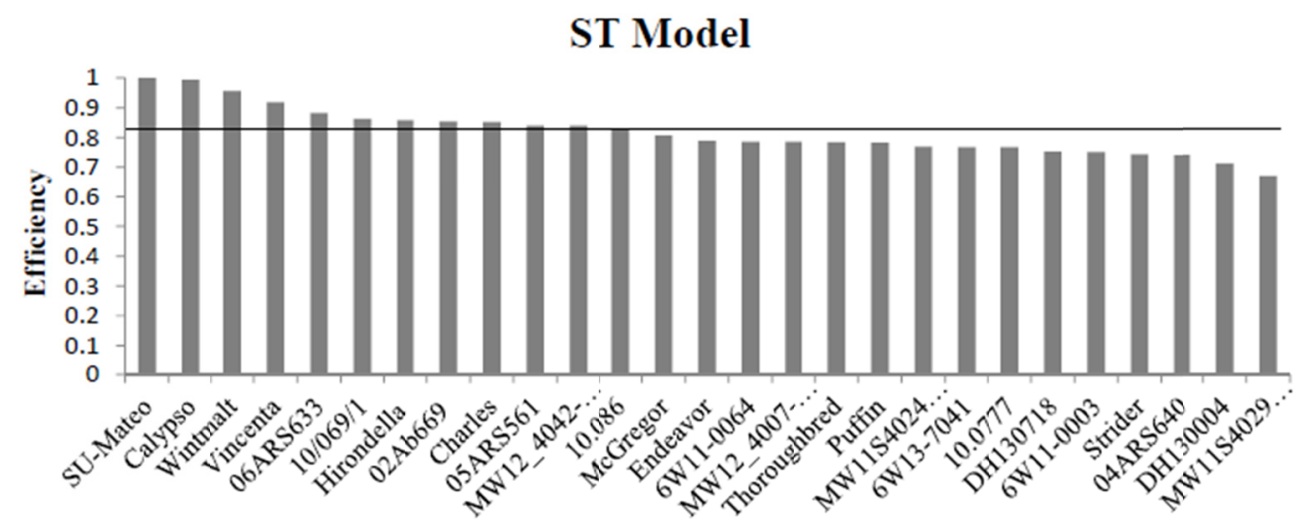

Figure 4. Efficiency ranking of winter barley varieties using the ST model

\section{Discussion}

While selection of high performing cultivars of many crops in testing trials is often based on yield performance, malting barley cultivars must meet several quality criteria for acceptance by maltsters. Malting industries currently use up to 15 criteria for acceptability of malting barley (BMBRI, 2015).

The results from this study indicated that DEA models could be used efficiently for testing genotypes with multi-criteria, especially when the number of entries is high.

Traditionally the two-row cultivars are preferred for malting purpose. However, in recent years, the high grain yield potential of six-row genotypes attracted attention of the growers. Results of the current study confirmed that on average the six-row entries out-yielded the two-row entries by approximately $18 \%$ (Table 2). However, implementation of DEA models revealed that the top four highest efficiency entries were amongst the two-row genotypes.

$\mathrm{Hu}$ et al. (2016) and Emrouznejad et al. (2014) suggested that there are two classical and widely used DEA models named CCR proposed by Charnes et al. (1978) and BCC which introduced by Banker et al. (1984). Later, two other models including FG model (Färe \& Grosskopf, 1985) and the ST model (Seiford \& Thrall, 1990) were introduced. The major feature of these models is that the adjustments of all inputs proportionally contracted without decreasing the amounts of current outputs. However, these models have a distinct property on returns to scale (RTS), indicating that for example CCR model presents constant returns to scale, while BCC model exhibits variant returns to scale.

Generally, outcomes of these models are not similar due to different assumptions on the frontiers. CCR, BCC, FG, and ST models provide four different frontiers, however efficiency of a DMU from the CCR model is always less than or equal to the efficiency calculated by other models. Moreover, the efficiency of a DMU from the FG or the ST model is less than or equal to the efficiencies calculated by BCC model. In other words, the models vary in aggressiveness with CCR model, followed by FG model as the most toughened ranking tool. In the current study when CCR and FG models performed, the maximum and minimum efficiencies were 1.0 and less than 0.2, respectively. However, using ST and BCC models resulted in efficiency range from 0.65-1.0.

\section{Conclusion}

The present study provides further evidence that it is of high importance to select malting barley cultivars for the growing craft malting industry. The result revealed that application of DEA model is very efficient due to having multiple number of testing entries and quality criteria.

\section{Acknowledgements}

This project was partially funded by the University of Massachusetts Amherst Agricultural Experiment Station and Northeast Sustainable Agriculture and Research Education (SARE) (LNE15-340).

\section{References}

American Malting Barley Association. (2018). Retrieved from http://ambainc.org/media/AMBA_PDFs/Pubs/ Malting_Barley_Breeding_Guidelines_June_2018.pdf

American Society of Brewing Chemists. (2004). Methods of analysis (9th ed.). The Society, St. Paul, MN, USA. 
Banker, R. D., Charnes, A., \& Cooper, W. W. (1984). Some models for estimating technical and scale inefficiencies in DEA. Manag Sci., 30, 1078-1092. https://doi.org/10.1287/mnsc.30.9.1078

Banker, R. D., Cooper, W. W., Seiford, L. M., \& Zhu, J. (2011). Returns to scale in DEA. International Series in Operations Research \& Management Science, 164, 41-70. https://doi.org/10.1007/978-1-4419-6151-8_2

BMBRI (Brewing and Malting Barley Research Institute). (2010). Quality factors in malting barley. Retrieved from http://bmbri.ca/wp-content/uploads/2016/10/Quality-Factors-in-Malting-Barley-May-2010.pdf

BMBRI (Brewing and Malting Barley Research Institute). (2015). Retrieved from http://bmbri.ca

Brouwer, B. O., Schwarz, P. B., Barr, J. M., Hayes, P. M., Murphy, K. M., \& Jones, S. S. (2016). Evaluating Barley for the Emerging Craft Malting Industry in Western Washington. Ag. J., 108, 939-949. https://doi.org/10.2134/agronj2015.0385

Charnes, A., Cooper, W. W., \& Rhodes, E. (1978). Measuring the efficiency of decision-making units. European Journal of Operational Research, 2, 429-444. https://doi.org/10.1016/0377-2217(78)90138-8

Darby, H., Cummings, E., Monahan, S., Post, J., \& Ziegler, S. (2014). Organic Spring Barley Variety Trial. Northwest crops and soils program. University of Vermont, USA.

Emrouznejad, A., Parker, B. R., \& Tavares, G. (2008). Evaluation of research in efficiency and productivity: A survey and analysis of the first 30 years of scholarly literature in DEA. Socio. Econ. Plann. Sci., 42, 151-157. https://doi.org/10.1016/j.seps.2007.07.002

Etemadi, F., Hashemi, M., Abbasi Shureshjani, R., \& Autio, W. (2017). Application of Data Envelopment Analysis to assess performance efficiency of eight faba bean varieties. Agron. J., 109, 1225-1231. https://doi.org/10.2134/agronj2016.10.0617

Färe, R., \& Grosskopf, S. (1985). A nonparametric cost approach to scale efficiency. J. of Economics, 87, 594-604. https://doi.org/10.2307/3439974

Johnson, D. D., \& Nganje, W. E. (2000). Impacts of DON in the malting barley supply chain: Aggregate costs and firm-level risks. Agricultural Economics Miscellaneous Report No. 187. Department of Agricultural Economics, Agricultural Experiment Station, North Dakota State University, USA.

Hu, J. L., \& Chang, T. P. (2016). Total-Factor Energy Efficiency and Its Extensions: Introduction, Computation and Application in Data Envelopment Analysis: A Handbook of Empirical Studies and Applications. International Series in Operations Research \& Management Science, 238, 45-70. https://doi.org/10.1007/ 978-1-4899-7684-0_3

Khokonova, M. B., Karashaeva, A. S., \& Zavalin, A. A. (2015). Quality of brewing malt depending on the storage conditions of barley. Russian Agricultural Sciences, 41, 508-511. https://doi.org/10.3103/S1068367 415060099

Kratochvil, B. (2017). Winter malting barley variety test. University of Maryland, Extension Agronomist. Retrieved from http://blog.umd.edu/agronomynews/2017/08/31/2017-winter-malting-barley-variety-test

MacArthur, L. A., D’Appolonia, B. L., \& Banasik, O. J. (2009). The Falling Number Test-What Is It and How Does It Work? North Dakota Agric. Exp. Sta. Farm Res., 38, 15-22.

Magliano, P. N., Prystupa, P., \& Gutiérrez - Boem, F. H. (2014). Protein content of grains of different size fractions in malting barley. Journal of the Institute of Brewing, 120, 347-352. https://doi.org/10.1002/jib.161

Mallet, J. (2014). Malt: A practical guide from Field to Brewhouse. Brew. Publ.

McFarland, A., Kapp, C., Russell, F., Isleib, J., \& Graham, S., (2014). Malting Barley Production in Michigan. Michigan State Univ. Extension Bulletin GMI, 035.

O’Donovan, J. T., Turkington, T. K., Edney, M. J., Clayton, G. W., McKenzie, R. H., Juskiw, P. E., ... May, W. E. (2011). Seeding rate, nitrogen rate, and cultivar effects on malting barley produuction. Ag. J., 103, 709-716. https://doi.org/10.2134/agronj2010.0490

Pasynkov, A. V., Zavalin, A. A., Pasynkova, E. N., \& Skorobogatykh, N. A. (2017). Change in quality parameters for brewing barley grain at fractionation. Russian Agricultural Sciences, 43, 371-375. https://doi.org/ $10.3103 / \mathrm{S} 1068367417050135$

Seiford, L. M., \& Thrall, R. M. (1990). The mathematical programming approach to frontier analysis. J. Econ. 46, 7-38. https://doi.org/10.1016/0304-4076(90)90045-U 
Smith, E. G., Turkington, T. K., O’Donovan, J. T., Edney, M. J., Juskiw, P. E., McKenzie, R. H., \& Irvine, R. B. (2016). Influence of production systems on return and risk from malting barley production in western Canada. Canadian Journal of Plant Science, 96, 339-346. https://doi.org/10.1139/cjps-2015-0129

Stevens, W. B., Sainju, U. M., Caesar-TonThat, T., \& Iversen, W. M. (2015). Malt Barley Yield and Quality Affected by Irrigation, Tillage, Crop Rotation, and Nitrogen Fertilization. Ag. J., 107, $2107-2119$. https://doi.org/10.2134/agronj15.0027

Tacke, B. K., \& Casper, H. H. (1996). Determination of deoxynivalenol in wheat, barley, and malt by column cleanup and gas chromatography with electron capture detection. Journal of AOAC International, 79, 472-475.

Thompson, R. G., Lee, E., \& Thrall, R. M. (1992). DEA/AR-efficiency of U.S. independent oil/gas producers over time. Comput. Oper. Res., 19, 377-391. https://doi.org/10.1016/0305-0548(92)90068-G

United States Department of Agriculture, N. A. S. S. (2015). Agricultural Prices August Farm Prices Received Index Up 3.0 percent.

Wrigley, C. (2010). Cereal grains: Assessing and managing quality (1st ed.).

Yu, G., Wei, Q. L., \& Brockett, P. (1996). A generalized data envelopment analysis model: A unification and extension of existing methods for efficiency analysis of decision making units. Ann. Oper. Res, 66, 47-89. https://doi.org/10.1533/9781845699529

\section{Copyrights}

Copyright for this article is retained by the author(s), with first publication rights granted to the journal.

This is an open-access article distributed under the terms and conditions of the Creative Commons Attribution license (http://creativecommons.org/licenses/by/4.0/). 